\title{
Magnetic resonance imaging for translational and basic life sciences
}

Ed $X \mathrm{Wu}^{1,2,3}$

From 2012 Sino-American Symposium on Clinical and Translational Medicine (SAS-CTM)

Shanghai, China. 27-29 June 2012

\section{Background}

With advances in engineering and computing, an extraordinary body of imaging technologies and applications has developed over the last 35 years. One of the most important applications of such technologies is the study of anatomy, physiology, pathology and functions in humans and animal models of human development and diseases. Among the various in vivo and non-invasive imaging modalities available or under development today, magnetic resonance imaging (MRI) is the most powerful and versatile technology platform. Its unparalleled in vivo and quantitative capabilities offer a broad range of applications covering from noninvasive morphologic measurements, tissue microstructural characterization, hemodynamic and vascular characterization, metabolite measurements, sub-system physiologies, brain functions to monitoring of cell migrational dynamics. This presentation will illustrate these technological developments with some of the ongoing rodent brain MRI projects in our laboratory, highlighting the capacity of MRI as a platform technology to visualize the central nervous system (CNS) in vivo from molecules to systems levels. They include diffusion characterization of neural tissue microstructure; functional study of molecular pathways by spectroscopy; functional study of brain development and injury; monitoring of endogenous neural stem cell activities; and novel contrast agents for brain imaging.

\section{Author details}

'Department of Electrical and Electronic Engineering, the University of Hong Kong, Hong Kong SAR, China. ${ }^{2}$ Laboratory of Biomedical Imaging and Signal Processing, the University of Hong Kong, Hong Kong SAR, China.

\footnotetext{
Correspondence: ewu@eee.hku.hk

'Department of Electrical and Electronic Engineering, the University of Hong Kong, Hong Kong SAR, China
}

Full list of author information is available at the end of the article
${ }^{3}$ Medical Engineering Program, the University of Hong Kong, Hong Kong SAR, China.

Published: 17 October 2012

doi:10.1186/1479-5876-10-S2-A29

Cite this article as: $\mathrm{Wu}$ : Magnetic resonance imaging for translational and basic life sciences. Journal of Translational Medicine 2012 10(Suppl 2): A29.
Submit your next manuscript to BioMed Central and take full advantage of:

- Convenient online submission

- Thorough peer review

- No space constraints or color figure charges

- Immediate publication on acceptance

- Inclusion in PubMed, CAS, Scopus and Google Scholar

- Research which is freely available for redistribution
() Biomed Central

\section{Biomed Central}

